\title{
Analysis of Proteins of Disease-Free and Didymascella thujina-Infected Leaves of Western Red-Cedar (Thuja plicata)
}

\author{
Harry H. Kope, Applied Forest Science Ltd., 4417 Bennett Road, Victoria, B.C. V9B 5T7, Canada, and Abul K. \\ M. Ekramoddoullah and Jack R. Sutherland, Canadian Forest Service, 506 W. Burnside Road, Victoria, B.C. \\ V8Z 1M5, Canada
}

\begin{abstract}
Kope, H. H., Ekramoddoullah, A. K. M., and Sutherland, J. R. 1998. Analysis of proteins of disease-free and Didymascella thujina-infected leaves of western red-cedar (Thuja plicata). Plant Dis. 82:210-212.

Analysis by sodium dodecyl sulfate-polyacrylamide gel electrophoresis (SDS-PAGE) of crude extracts of disease-free and Didymascella thujina-infected foliage of western red-cedar revealed differences in several protein bands and suggests that distinct proteins of $D$. thujina origin can be identified by SDS-PAGE.
\end{abstract}

Additional keywords: conifer seedling, diagnostic technique, Keithia leaf blight, reforestation

Didymascella thujina (E.J. Durand) Maire (formerly Keithia thujina E.J. Durand), a fungal pathogen endemic to North America, parasitizes the leaves and stems of Thuja species. Keithia leaf blight was first recorded in Wisconsin on eastern white cedar (Thuja occidentalis L.) in 1908 (1), and from 1912 to 1915 , the disease was reported as seriously affecting western red-cedar (Thuja plicata Donn ex D. Don) in Idaho (16). Most observations of Keithia leaf blight are on western red-cedar, which is the most susceptible host. The pathogen occurs throughout the range of western red-cedar and throughout Europe on $T$. plicata and T. occidentalis, where it was probably introduced on cedars imported from North America or on seeds, cones, or debris of cedar (13).

Although all age classes of western redcedar are susceptible, nursery seedlings and young reforestation seedlings are affected the most. Observations have shown that blight incidence in the nursery is low during the first growing season but intensifies during the second season, when it often reaches epiphytotic levels on container-grown seedlings (8) and bareroot nursery transplants (14). In British Columbia, the disease has become especially severe on 2-year-old container-grown $(2+$ $0)$ and 2-year-old transplant $(1 p+1)$ western red-cedar (8). Besides within-nursery seedling losses, additional losses can result when infected but asymptomatic seedlings

Present address of Harry H. Kope: Contact Biologicals, 17 Jedburgh Road, Victoria, B.C. V9B 1K7, Canada; E-mail: hkope@islandnet.com

Accepted for publication 22 October 1997.

Publication no. D-1997-1201-02R

(C) 1998 The American Phytopathological Society are transplanted into field beds or used for reforestation $(9,15)$.

The pathogen spreads among and between healthy plants via ascospores forcibly released from apothecia. Ascospores of D. thujina, an obligate parasite, infect only the newly formed foliage during the first growing season; however, the infected leaves remain symptomless. After ascospores germinate and penetrate cedar leaf tissue, mycelial growth remains restricted to the mesophyll tissue of individual leaves and ramifies throughout the leaf without penetrating the vascular bundle (12). During the second growing season, the infection becomes conspicuous when apothecia develop on either the juvenile, needle-like leaves on the stem or the mature, scale-like leaves on the branches.

Disease diagnosis and management are difficult since the fungus can not be cultured, the anamorph is unknown, and the latency period between infection and symptom expression is long. Thus, remedial action cannot be taken until well after the disease is established.

The objective of this study was to determine whether sodium dodecyl sulfatepolyacrylamide gel electrophoresis (SDSPAGE) could be used as a technique to distinguish differences in protein content of disease-free western red-cedar leaves and D. thujina-infected leaves.

\section{MATERIALS AND METHODS}

Three types of material were sampled: (i) disease-free western red-cedar leaves, (ii) infected leaves, and (iii) fungal material made of $D$. thujina apothecia. Diseasefree leaves, infected leaves, and apothecia were collected from 2-year-old containergrown western red-cedar seedlings (BC Ministry of Forests, seedlot 20202) in July 1993.
Western red-cedar seedlings were grown in 10 VENTBLOCK (Beaver Plastics, Edmonton, Alberta) seedling growing containers (176 seedlings per block), cavity size 313B, for two growing seasons (1992 $+1993)$. The seedlings were grown in a greenhouse to avoid infection via airborne ascospores of $D$. thujina. Disease-free juvenile and mature leaves of western redcedar were sampled from five seedlings. To verify that the material was diseasefree, the seedlings were grown for one additional growing season (1994) under conditions conducive to disease expression, namely high humidity $(>80 \%)$ and warm temperatures $\left(>10^{\circ} \mathrm{C}\right)(12)$. No signs of the pathogen were found after this growing period.

Another set of western red-cedar seedlings in 10 VENTBLOCK 313B seedling growing containers were grown for two growing seasons $(1992+1993)$ under conditions conducive to disease development and expression, as described; and infected juvenile and mature leaves of western redcedar were collected. During the second growing season, infected seedlings had conspicuous signs of $D$. thujina.

To obtain fungal material for protein extraction and comparisons, the apothecia of $D$. thujina were carefully excised from infected leaves of diseased seedlings. A subsample of 10 excised apothecia was plated onto $2 \%$ malt extract agar to determine whether contaminating microorganisms were associated with the apothecia.

Disease-free and infected leaves of western red-cedar and the apothecia of $D$. thujina were extracted for proteins as described by Ekramoddoullah $(2,4)$, with minor modifications. Samples were lyophilized and ground to a powder in liquid nitrogen with a mortar and pestle, after which $50 \mathrm{mg}$ of the powder was extracted with $0.7 \mathrm{ml}$ of ES (4\% SDS, 5\% sucrose, $5 \%$ mercaptoethanol) for $10 \mathrm{~min}$ at room temperature with gentle stirring. The extract was centrifuged at $10,000 \times g$, and the clear supernatant was heated at $100^{\circ} \mathrm{C}$ for 3 min and then cooled to room temperature. Proteins were precipitated by adding cold $\left(-20^{\circ} \mathrm{C}\right)$ acetone $(8 \times$ volume of the supernatant). Precipitation was allowed to continue for $1 \mathrm{~h}$, after which the sample was centrifuged at $10,000 \times g$. The pellet was resuspended in $0.2 \mathrm{ml}$ of ES and centrifuged at $10,000 \times g$, and the protein content of the supernatant was determined 
$(3,5)$ using bovine serum albumin (BSA) as a standard. The protein solution was spotted on a polyvinylidene difluoride membrane (Immobilon-P, Millipore Canada Ltd., Toronto, Ontario). The membrane was stained with $0.1 \%$ Coomassie blue R250 (Bio-Rad Laboratories, Richmond, CA) in $50 \%$ methanol for $8 \mathrm{~min}$ and then destained in 50\% methanol:10\% acetic acid for $8 \mathrm{~min}$ at room temperature. The membrane was then rinsed with water for $10 \mathrm{~min}$. The stained membrane was scanned by a laser scanner (Molecular Dynamics, Model 110A, Sunnyvale, CA) interfaced with a workstation (SPARK 1, Sun Microsystems of Canada Inc., Vancouver, B.C.) and PDI (Protein + DNA ImageWare Systems, Huntington Station, NY) for membrane blot processing with the software program ONED. Scanning, detection, and quantification were done according to the PDI instruction manual.

SDS-PAGE was carried out in the protein slab cell apparatus (Bio-Rad) with $0.75-\mathrm{mm}$ spacers utilizing the Laemmli buffer system (10), at $15^{\circ} \mathrm{C}$ and $\mathrm{pH}$ 8.8. A sample volume of $10 \mu \mathrm{l}$ (containing $5 \mu \mathrm{g}$ of protein) was applied in each well. To calibrate the gel, low molecular weight (range: 14.4 to $97 \mathrm{kDa}$ ) standard markers (Bio$\mathrm{Rad})$ were used. The gel was stained with silver (7). To quantify separated protein bands and to match bands among diseasefree, infected, and fungal tissue, stained gels were scanned by laser scanner (Molecular Dynamics) interfaced by PDI with ONED software for processing onedimensional gels. An original version of the software program was described by Garrels et al. (6).

Proteins separated by SDS-PAGE were electrophoretically transferred to Immobilon-P membrane, as described by Matsudaira (11). For sequencing, the stained protein bands were cut from the membrane and placed directly (11) into the sequencer (Model 470A, Applied Biosystems, Foster City, CA) for $\mathrm{N}$-terminal sequence analysis according to the manufacturer's instruction manual. The amino acid analyses were performed at the University of Victoria microsequencing facility (Victoria, B.C., Canada).

\section{RESULTS AND DISCUSSION}

Apothecia of D. thujina occur on both juvenile and mature leaves of cedar; however, when disease expression first occurs, it is often limited to juvenile leaves. Infected and disease-free juvenile and mature leaves were assayed and compared for protein differences between the leaf types. Protein bands were identical for juvenile and mature leaves of both infected and disease-free leaves, suggesting the two leaf types could be bulked when assaying putative infections.

A comparison of disease-free and infected mature leaves showed distinct protein band differences. Figure 1 shows three protein bands (115.8 kDa, $27.4 \mathrm{kDa}, 22.5$ $\mathrm{kDa}$ ) that were observed only in the lanes of infected leaf material. These proteins were not present in the disease-free tissue of the five seedlings, suggesting that they were the result of the infecting fungus. The quantities of the three fungal proteins, $115.8,27.4$, and $22.5 \mathrm{kDa}$, had average optical densities of $0.67 \pm 0.24,0.58 \pm$ 0.05 , and $0.52 \pm 0.06$, respectively, showing little variation among the five seedlings. The majority of protein bands observed in disease-free leaves were present in the infected leaves but in lower quantities.

Excised apothecia plated onto $2 \%$ malt agar were not contaminated by heterotrophic organisms. The fungal material of the excised apothecia were compared for protein content with infected mature leaves. The fungal material contained three protein bands that were similar to those of a sample of the infected leaf material (Fig. 1).

An attempt was made to partially sequence the three putative fungal proteins; however, N-terminal amino acids of all three proteins were blocked and did not allow amino acid sequencing. Internal amino acid sequencing was not attempted.

The data presented in this paper demonstrate that proteins of the pathogen could be detected in the infected leaves. The method also differentiated between disease-free and infected leaves. Further purification and characterization of these proteins would lead to the development of a sensitive immunochemical diagnostic method for detecting this pathogen in infected, asymptomatic leaves.

\section{ACKNOWLEDGMENTS}

We thank Doug Taylor, Win Zhong, and Mary Morrison for technical assistance. This work was funded by Natural Resources Canada under the Canada-British Columbia Forest Development Agreement II.

\section{LITERATURE CITED}

1. Durand, E. J. 1909. Transactions of the Wisconsin Academy of Sciences, Arts and Letters 16:756.

2. Ekramoddoullah, A. K. M. 1991. Analysis of proteins of western white pine (Pinus monticola Dougl.) needles. Pages 102-108 in: Rusts of Pine. Proc. IUFRO Rusts of Pine Working Party Conference, 3rd. Y. Hiratsuka, J. K Samoil, P. V. Blenis, P. E. Crane, and B. L. Laishley, eds. For. Can., Northwest Reg., North. For. Cent., Edmonton, Alberta. Inf Rep. Nor-X-317.

3. Ekramoddoullah, A. K. M. 1992. An innovative approach to determination of nanogram quantities of protein whereby the interference by sodium dodecyl sulfate (SDS) and mercaptoethanol was eliminated. FASEB J. 6:No. 4 and 5, 1992.

4. Ekramoddoullah, A. K. M. 1993. Analysis of needle proteins and $\mathrm{N}$-terminal amino acid sequence of two photosystem II proteins of western white pine (Pinus monticola D. Don.). Tree Physiol. 12:101-106.

5. Ekramoddoullah, A. K. M., and Davidson, J. J. 1995. A method for the determination of conifer foliage protein extracted using sodium dodecyl sulfate and mercaptoethanol. Phytochem. Anal. 6:20-24.

6. Garrels, J. I., Farrar, J. T., and Burwell, C. B.,
Fig. 1. Sodium dodecyl sulfate-polyacrylamide gel electrophoresis (SDS-PAGE) analysis of total proteins extracted from apothecia of Didymascella thujina and from infected mature leaves and disease-free mature leaves of five western red-cedar seedlings. Lane 1 shows the separation pattern of total proteins from apothecia of D. thujina. Lanes 2, 4, 6, 8, and 10 show the separation pattern for total protein of $D$. thujina-affected mature leaves. Lanes 3, 5, 7, 9, and 11 show the separation patterns of total protein of disease-free mature leaves. Positions of standard molecular weight markers are indicated on the right side, and the positions of three fungal bands unique to the infected leaves (i.e., fungal proteins) are shown on the left side of the figure. 
IV. 1984. The QUEST system for computeranalyzed two-dimensional electrophoresis of proteins. Pages 37-91 in: Two-Dimensional Gel Electrophoresis of Proteins (Methods and Applications). J. E. Celis and R. Bravo, eds. Academic Press, New York.

7. Hochstrasser, D. F., Harrington, M. G., Hochstrasser, A.-C., Miller, M. J., and Merril, C. R. 1988. Methods for increasing the resolution of two-dimensional protein electrophoresis. Anal. Biochem. 173:424-435.

8. Kope, H. H., and Sutherland, J. R. 1994. Keithia blight: A review of the disease, and research on container-grown western redcedar in British Columbia, Canada. Pages 2744 in: Diseases and Insects in Forest Nurseries. "Les colloques" series nº8. R. Perrin and J. R. Sutherland, eds. Institute National de la Recherche Agronomique, Versailles, France.

9. Kope, H. H., Sutherland, J. R., and Trotter, D. 1996. Influence of cavity size, seedling growing density and fungicide applications on Keithia blight of western redcedar seedling growth and field performance. New Forests 11:137-147.

10. Laemmli, U. K. 1970. Cleavage of structural proteins during the assembly of the head of bacteriophage T4. Nature 227:680-685.

11. Matsudaira, P. 1987. Sequence from picomole quantities of proteins electroblotted onto polyvinylidene difluoride membranes. J. Biol. Chem. 262:10035-10038.

12. Pawsey, R. G. 1960. An investigation into Keithia disease of Thuja plicata. Forestry 33:174-186.
13. Peace, J. R. 1962. Pathology of trees and shrubs. Clarendon Press, Oxford.

14. Phillips, D. H., and Burdekin, D. A. 1982 Diseases of Forest and Ornamental Trees. Macmillan Press Ltd., London.

15. Trotter, D., Shrimpton, G., and Kope, H 1994. The effect of Keithia blight on outplanting performance of Western redcedar container seedlings at two reforestation sites in British Columbia: Preliminary results. Pages 196-202 in: National Proceedings, Forest Conservation Nursery Associations. T. D. Landis and R. K. Dumroese, tech. coord. U.S Dep. Agric. For. Ser. Gen. Tech. Rep. RM257.

16. Weir, J. R. 1916. Keithia thujina. The cause of serious leaf disease of western redcedar. Phytopathology 6:360-363. 